\title{
Pengaruh Zakat Terhadap Indeks Pembangunan Manusia dan Tingkat Kemiskinan Mustahik : Studi Kasus Pendayagunaan BAZNAS Kota Bogor
}

\section{Influence of Zakat on Human Development Index and Poverty Level of Mustahik: Case Study of BAZNAS Utilization in Bogor}

\author{
Rina Murniati' ${ }^{1}$ Irfan Syauqi Beik ${ }^{2}$ \\ ${ }^{1}$ Peneliti IMZ, Email : rinamipb@gmail.com \\ ${ }^{2}$ Pusat Studi Bisnis dan Ekonomi Syariah (Center of Islamic Business and Economic Studies) IPB \\ Email : qibeiktop@yahoo.com; irfan_beik@ipb.ac.id
}

\begin{abstract}
This research aims at analyzing zakat distribution program of BAZNAS of Bogor City and its impact towards mustahik life based on the income changes after zakat and the values of post-zakat Human Development Index (HDI) and poverty reduction. By utilizing t-statistics, individual HDI, and poverty indicators, this study concludes that zakat has positive impact in increasing human development of mustahik in Bogor city. T-statistics result shows that theres is significant impact of zakat on the mustahik income. HDI value indicates that there is an increase from 47 to 49 in the presence of zakat. As for poverty indicators, all indices used portray significant reduction in the poverty level of mustahik. This could be observed from the reduction in the values of headcount ratio index $(\mathrm{H})$, poverty gap index $\left(\mathrm{P}_{1}\right)$, income gap indeks $(\mathrm{I})$, and Sen indeks of poverty $(\mathrm{P} 2)$, respectively.
\end{abstract}

Keywords : Zakat, Human Development, Poverty, BAZNAS of Bogor City

Abstrak. Penelitian ini bertujuan untuk menganalisis program pendayagunaan zakat yang dilakukan BAZNAS Kota Bogor serta dampaknya terhadap kehidupan mustahik, baik ditinjau dari perubahan pada pendapatan mustahik pasca distribusi zakat, maupun dari sisi nilai IPM dan tingkat kemiskinan mustahik. Dengan menggunakan metode perhitungan t-statistik, indeks pembangunan manusia (IPM) tingkat individu, serta indikator kemiskinan, maka dapat disimpulkan bahwa zakat berperan positif dalam meningkatkan pembangunan manusia mustahik di kota Bogor. Hasil uji t-Statistik menunjukkan bahwa pemberian zakat kepada mustahik memberikan pengaruh nyata pada tingkat pendapatannya. Begitu juga dengan nilai IPM mustahik yang mengalami peningkatan dari angka 47 sebelum distribusi zakat menjadi 49 setelah distribusi zakat. Hasil studi menunjukkan adanya penurunan pada tingkat kemiskinan mustahik berdasarkan pada empat indikator kemiskinan yang digunakan, yaitu headcount ratio index $(\mathrm{H})$, poverty gap index $\left(\mathrm{P}_{1}\right)$, income gap indeks $(\mathrm{I})$, dan Sen indeks of poverty (P2).

Kata kunci : Zakat, Pembangunan Manusia, Kemiskinan, BAZNAS Kota Bogor

\section{Pendahuluan}

Saat ini zakat semakin berperan menjadi salah satu instrumen dalam pembangunan manusia, khususnya di Indonesia. Konsep zakat sebagaimana yang dikatakan Beik (2010), pada dasarnya memiliki tiga dimensi pokok, yaitu dimensi spiritual personal, dimensi sosial, dan dimensi ekonomi. Zakat merupakan sarana ibadah dan penyucian jiwa seseorang. Dengan berzakat produktivitas individual akan meningkat, karena zakat mendorong seseorang untuk memiliki etos kerja yang tinggi. Dalam dimensi ekonomi, Beik lebih lanjut menjelaskan bahwa zakat memiliki dua konsep utama, yaitu pertumbuhan ekonomi berkeadilan dan mekanisme sharing dalam perekonomian. Jika dikaji lebih mendalam, ketiga dimensi di atas memiliki hubungan positif dengan parameter pembangunan manusia yang terdiri atas kesehatan, pendidikan, dan standar hidup layak.

Di sisi lain, zakat juga memiliki korelasi dengan variabel pertumbuhan ekonomi. Pramanik (1993) menyatakan bahwa zakat berpengaruh pada investasi dan produksi, saving, dan konsumsi. Pada sisi investasi, zakat dapat dijadikan sebagai sumber dana produktif bagi pengembangan usaha mikro penerima zakat (mustahik). Pengembangan usaha mikro ini bisa membantu perekonomian Indonesia dan relatif memiliki daya tahan lebih besar dalam situasi krisis ekonomi. Pada sisi konsumsi, 
pemberian zakat dapat menstimulus peningkatan aggregate demand (permintaan agregat). Kenaikan permintaan agregat akan mendorong peningkatan dari sisi supply, sehingga perekonomian akan semakin berkembang. Namun, efektivitas penggunaan zakat sebagai instrumen peningkatan pembangunan akan dipengaruhi oleh aspek kinerja lembaga-lembaga zakat dan potensi dana zakat itu sendiri.

Indonesia merupakan salah satu negara dengan potensi zakat yang cukup besar. Berdasarkan studi yang dilakukan Badan Amil Zakat Nasional (BAZNAS) dengan Institut Pertanian Bogor dan Islamic Development Bank pada tahun 2011, potensi zakat nasional mencapai angka Rp 217.3 triliun per tahun. Meskipun realisasi zakat masih dibawah satu persen dari proyeksi, namun pertumbuhan zakat nasional terus menunjukkan pertumbuhan yang signifikan. BAZNAS (2013) mencatat untuk tahun 2012, dana zakat yang berhasil dihimpun mencapai Rp 2.2 triliun, mengalami kenaikan dari tahun sebelumnya sebesar Rp 1.7 triliun dan tahun 2010 sebesar Rp 1.5 triliun. Jika dibandingkan dengan dana yang dikeluarkan pemerintah pusat untuk menanggulangi kemiskinan yaitu sekitar Rp 70 triliun setiap tahun, maka zakat dapat membantu setidaknya 1.7 juta mustahik yang setara dengan enam persen warga miskin.

Sejak diberlakukannya UU No 38 Tahun 1999 tentang Pengelolaan Zakat yang kemudian diganti oleh UU No 23 Tahun 2011, maka perkembangan Badan Amil Zakat Nasional (BAZNAS) dan Lembaga Amil Zakat (LAZ) semakin baik di setiap daerah di Indonesia. Salah satu BAZNAS yang memiliki perkembangan sangat baik adalah BAZNAS Kota Bogor. Sejak awal berdiri hingga sekarang, BAZNAS Kota Bogor, yang dahulunya bernama BAZDA Kota Bogor, telah memiliki banyak prestasi. Sebagai contoh, menjadi BAZ Kota/Kabupaten terbaik tingkat nasional tahun 2009 untuk kategori Kreativitas Program Pendayagunaan versi BAZNAS, dan pada tahun 2009 mendapat peringkat dua sebagai BAZ Kota/Kabupaten terbaik versi Islamic Social Responsibility. Hal ini karena kemampuan BAZNAS Kota Bogor dalam membuat inovasi program-program pendayagunaan dana zakat. Program-program tersebut meliputi bidang pendidikan, kesehatan, ekonomi, dan kemanusiaan.

Sepanjang tahun 2009 sampai dengan tahun 2011, angka penerimaan ZIS (zakat, infak dan sedekah) di BAZNAS Kota Bogor menunjukkan peningkatan. Tahun 2009, pertumbuhan ZIS meningkat dalam kisaran 100 persen dibanding tahun 2008. Begitu juga penerimaan ZIS tahun 2010 dan tahun 2011. Sampai akhir tahun 2011, jumlah dana ZIS yang dihimpun BAZNAS Kota Bogor bersama mitra BAZ yaitu

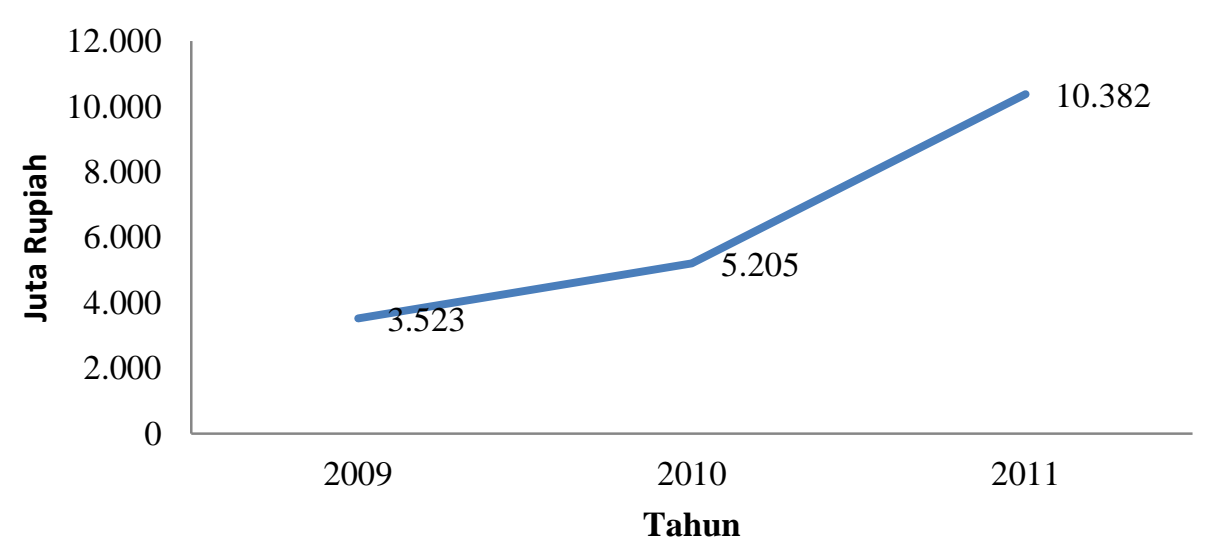

pengumpul zakat (UPZ) Masjid, UPZ Sekolah, UPZ Dinas, dan BAZ Kecamatan, telah mencapai Rp 10,38 milyar. Hal ini sebagaimana dapat dilihat pada Gambar 1. 
Sumber : BAZNAS Kota Bogor 2013

\section{Gambar 1 Total Penerimaan ZIS BAZNAS Kota Bogor dan Mitra BAZ}

Sedangkan dari sisi penyaluran, pada kurun waktu 2009-2011 program-program pendayagunaan BAZNAS Kota Bogor telah terorganisir berdasarkan asnaf, dengan proporsi penyaluran terbesar pada asnaf sabilillah sebesar Rp 696,7 juta. Dana tersebut disalurkan pada program pendidikan, syiar, dan kesehatan. Proporsi terbesar kedua adalah asnaf miskin dengan angka Rp 499,56 juta yang tersalur pada program kemanusiaan, kesehatan, pendidikan, dan ekonomi. Kemudian, proporsi anggaran terbesar berikutnya adalah asnaf fakir dengan angka $\mathrm{Rp} 369,28$ juta yang tersalur pada program kemanusiaan. Secara lengkap adalah sebagaimana yang ditunjukkan oleh Gambar 2.

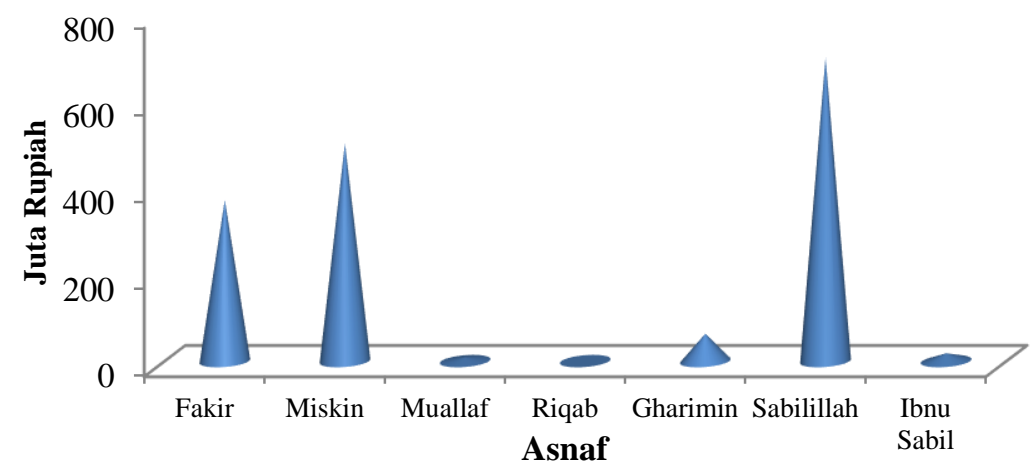

Sumber : BAZNAS Kota Bogor 2013

\section{Gambar 2 Distribusi Penyaluran Berdasarkan Asnaf Tahun 2009-2011}

Jika ditinjau secara umum, kota Bogor merupakan salah satu kota dengan jumlah penduduk yang sangat besar. Sensus penduduk tahun 2010 mencatat jumlah penduduk kota Bogor mencapai angka 949 ribu jiwa dengan laju pertumbuhan rata-rata sebesar 2.39 persen. Diperkirakan pada tahun 2013 penduduk kota Bogor mencapai angka satu juta penduduk. Namun, jumlah penduduk yang besar tersebut belum diimbangi dengan tingkat kesejahteraan yang merata. Pada tahun 2012, angka penduduk miskin mencapai 8.6 persen dari total jumlah penduduk dan angka pengangguran terbuka mencapai 10.2 persen. BPS juga mencatat nilai IPM (Indeks Pembangunan Manusia) kota Bogor yang cukup tinggi, dimana angkanya mencapai 76.06 pada tahun 2013. Fakta ini terlihat sangat paradoks, dimana dari data-data yang dipublikasikan oleh pemerintah tidak memiliki korelasi satu sama lain. Karena itu, diperlukan penelitian lebih mandalam untuk mengetahui bagaimana kondisi yang sebenarnya terjadi.

Untuk itu, penelitian ini dilaksanakan dengan maksud untuk menjawab sejumlah rumusan masalah, yaitu :

1. Apakah terjadi perubahan pendapatan mustahik sebelum dan sesudah menerima zakat?

2. Bagaimana pengaruh zakat terhadap tingkat IPM mustahik?

3. Bagaimana pengaruh zakat terhadap tingkat kemiskinan mustahik?

Penelitian ini dilaksanakan dengan mengambil studi kasus pendayagunaan BAZNAS Kota Bogor. Diharapkan penelitian ini dapat memberikan gambaran yang utuh tentang pengaruh zakat terhadap perubahan pendapatan mustahik pasca zakat, tingkat IPM dan kemiskinan mereka. 


\section{Tinjauan Pustaka}

Konsep pembangunan awalnya mengacu pada pengertian pembangunan secara ekonomi. Meier (1998) mengatakan dalam bukunya, Leading Issues in Economic Development, bahwa pembangunan merupakan suatu proses dimana pendapatan perkapita riil dari suatu negara meningkat dalam jangka waktu yang lama dan dalam jangka waktu yang bersamaan jumlah penduduk yang berada di bawah garis kemiskinan tidak bertambah, serta distribusi pendapatan tidak semakin senjang. Sejalan dengan apa yang terjadi di negara-negara sedang berkembang (NSB) saat ini, konsep pembangunan ekonomi lebih menekankan pada proses kenaikan Gross National Product (GNP) dan Gross Domestic Product (GDP) tanpa memerhatikan kondisi pertumbuhan penduduk dan perubahan struktur ekonomi. Penekanan pada peningkatan angka GNP dan GDP tanpa memerhatikan penambahan jumlah penduduk memungkinkan terjadinya kekeliruan dalam memahami prestasi kegiatan ekonomi. Karena pada saat perhitungan kenaikan GNP atau GDP, suatu negara juga mengalami pertumbuhan penduduk.

Namun demikian, beberapa pemikiran lain seperti yang terdapat dalam literatur ekonomi klasik yang disampaikan oleh Adam Smith, Keynes, dan Alfred Marshal, bahwasanya ada suatu dimensi lain yang juga sangat penting dalam pembangunan, yakni sumber daya manusia. Kualitas sumber daya manusia merupakan sebuah faktor produksi yang dapat diukur dari kondisi fisik, tingkat pendidikan dan keterampilan yang dimilikinya. Semua kondisi tersebut dapat diukur dengan angka, karena itu kualitas sumber daya manusia sebuah negara juga dapat diukur dengan angka (Marzali 2007). Hal ini semakin diperkuat dengan pemikiran Soedjatmoko (1995) bahwa pembangunan hanya akan terlihat seutuhnya apabila pembangunan itu merupakan proses pembangunan manusia.

Sementara itu, dimensi tujuan pembangunan menjelaskan bagaimana urutan tahapan evolusi pengukuran ekonomi pembangunan, mulai dari kemunculan teori ekonomi pembangunan yang mengukur terjadinya pembangunan dilihat dari tingkat output melalui PDB berkembang menggunakan indeks pembangunan manusia (IPM), mengatasi kemiskinan dengan paradigma entitlements dan kapabilitas, kebebasan, hingga pembangunan berkelanjutan (Kuncoro 2010). Pada akhir dasawarsa 1960-an, banyak NSB (Negara Sedang Berkembang) mulai menyadari bahwa pertumbuhan (growth) tidak identik dengan pembangunan (development). Pertumbuhan ekonomi yang tinggi tidak diimbangi dengan penyelesaian masalah-masalah seperti pengangguran, kemiskinan, dan ketimpangan distribusi pendapatan. Hal ini memperkuat keyakinan bahwa pertumbuhan ekonomi merupakan syarat yang diperlukan (necessary), tetapi tidak mencukupi (sufficient) bagi proses pembangunan. Dengan kata lain, pembangunan ekonomi tidak lagi menjadikan GNP sebagai sasaran utama pembangunan, tetapi lebih memfokuskan pada kualitas proses pembangunan (Kuncoro, 2010).

Dalam konteks hubungan antara IPM dan zakat, studi yang dilakukan masih sangat jarang. Diantara studi yang telah dilakukan adalah penelitian Nurzaman (2010). Nurzaman (2010) membahas dampak dari efektifitas zakat produktif dalam meningkatkan kesejahteraan penerima zakat (mustahik) dengan menggunakan indikator kesejahteraan yang tidak hanya diukur dari indikator ekonomi, tapi juga mencakup pendidikan dan kesehatan yang dirangkum dalam IPM. Nilai IPM yang digunakan adalah tingkat rumah tangga yang dibandingkan dengan rata-rata nilai IPM tingkat regional dan nasional, kemudian diuji apakah zakat memengaruhi nilai IPM dan komponen-komponennya. Hasil estimasi dari IPM ini menunjukkan bahwa nilai rata-rata mencapai 69.43. Nilai tersebut masih di bawah ratarata IPM Jakarta (77.36) dan tingkat nasional (71.76). Penerima zakat produktif, dengan metode regresi juga secara tidak langsung mempengaruhi IPM. Namun yang menarik, zakat ini memiliki efek pada perubahan alokasi pendapatan dan konsumsi untuk tujuan produktif.

Adapun terkait hubungan antara zakat dan pengentasan kemiskinan, telah banyak studi yang mengaitkan diantara keduanya, baik secara konseptual maupun secara empiris. Qardhawi (2001) sebagai contoh, menegaskan bahwa diantara tujuan ibadah zakat adalah mengentaskan beragam persoalan masyarakat seperti kemiskinan dan kesenjangan pendapatan. Penyebutan asnaf fakir dan miskin sebagai dua kelompok pertama penerima zakat dalam Al Quran menunjukkan bahwa ibadah 
zakat bertujuan untuk mengurangi angka kemiskinan dan kesenjangan pendapatan diantara kelompok kaya dengan kelompok miskin (Hafidhuddin, 2002).

Secara empiris, di antara studi yang telah dilakukan antara lain adalah Beik (2009), Tsani (2010) dan Anriani (2010). Beik (2009) membahas secara empirik dampak zakat terhadap upaya pengurangan tingkat kemiskinan, dengan mengambil studi kasus Lembaga Amil Zakat Nasional (LAZNAS) Dompet Dhuafa Republika. Penelitian ini menggunakan sejumlah alat analisis, yaitu : headcount ratio, untuk mengetahui berapa jumlah dan presentase keluarga miskin; rasio kesenjangan kemiskinan dan rasio kesenjangan pendapatan digunakan untuk mengetahui tingkat kedalaman kemiskinan; serta indeks Sen dan indeks Foster Greer Thorbacke (FGT) untuk mengukur tingkat keparahan kemiskinan. Hasil analisis menunjukkan bahwa zakat mampu mengurangi jumlah dan presentase keluarga miskin, serta mengurangi tingkat kedalaman dan keparahan kemiskinan mustahik.

Tsani (2010) membahas dampak zakat terhadap kemiskinan dan kesenjangan pendapatan yang dilakukan oleh Bazda Lampung Selatan. Terdapat 120 responden yang terdiri dari 80 mustahik dan 40 muzakki. Metode yang digunakan adalah pengujian dengan menggunakan t-statistik untuk mengetahui apakah pemberian zakat berpengaruh nyata terhadap tingkat kemiskinan mustahik atau tidak. Kemudian, dilakukan analisis indikator kemiskinan dengan menggunakan headcount ratio, untuk mengetahui berapa jumlah dan presentase keluarga miskin, rasio kesenjangan kemiskinan dan rasio kesenjangan pendapatan digunakan untuk mengetahui tingkat kedalaman kemiskinan, dan indeks FGT untuk mengukur tingkat keparahan kemiskinan. Hasil penelitian membuktikan bahwa pada taraf nyata 5 persen, pendistribusian zakat oleh BAZDA Lampung Selatan berpengaruh signifikan dan positif terhadap pendapatan keluarga mustahik. Pendistribusian zakat ini mampu mengurangi beban kemiskinan dan kesenjangan pendapatan tidak hanya pada mustahik namun juga pada muzakki. Hal ini dibuktikan dengan indeks gini yang menurun dari 0.638 menjadi 0.625 dan rasio Kuznets yang menurun dari 16.7 menjadi 14.4.

Anriani (2010) membahas tentang dampak zakat terhadap kemiskinan dengan mengambil studi kasus pendayagunaan zakat oleh BAZDA Kota Bogor. Pengumpulan data dari wawancara yang dilakukan kepada 100 responden yang tersebar di tiga kecamatan yaitu: Kecamatan Bogor Tengah, Bogor Barat, dan Bogor Timur. Hasil penelitian menunjukkan adanya penurunan pada semua indikator kemiskinan. Ini menunjukkan bahwa ternyata zakat berdampak positif terhadap penurunan tingkat kemiskinan di tiga kecamatan tersebut.

Dari penelusuran literatur ini, kajian empiris pengaruh zakat terhadap indeks pembangunan manusia dan tingkat kemiskinan dalam satu penelitian masih sangat jarang. Karena itu, signifikansi penelitian yang dilakukan ini adalah mengisi gap literatur pengaruh zakat terhadap dua hal sekaligus, yaitu tingkat IPM dan tingkat kemiskinan mustahik.

\section{Metode Penelitian}

\subsection{Jenis dan Sumber Data}

Jenis data yang digunakan dalam penelitian ini adalah data primer dan data sekunder. Data primer diperoleh dari hasil wawancara dengan mustahik yang terdaftar sebagai penerima program pendayagunaan zakat BAZNAS Kota Bogor. Wawancara dilakukan kepada 60 responden yang di bagi ke dalam dua kategori. Kategori pertama merupakan 30 orang mustahik dari program kesehatan dengan sub program aktivitas klinik. Kategori kedua merupakan 30 orang mustahik dari program kemanusiaan dengan sub program paket senyum. Data sekunder diperoleh dari laporan tiga tahunan BAZNAKota Bogor, Badan Pusat Statistik Kota Bogor, United Nations Development Programme (UNDP), World Health Organization (WHO), jurnal, artikel, skripsi, buku, dan internet. 


\subsection{Lokasi dan Waktu Penelitian}

Penelitian ini dilakukan didua kategori lokasi yang berbeda. Lokasi pertama di Poliklinik Ibnu Sina Tirta Pakuan, Bogor. Pemilihan lokasi ini dengan pertimbangan bahwa polilklinik ini sudah memiliki manajemen administrasi yang baik, sehingga data yang dibutuhkan lebih mudah diperoleh. Selain itu, poliklinik ini juga lebih baik dalam hal pelayanan, sehingga memudahkan peneliti untuk melakukan wawancara dengan pasien.

Sedangkan lokasi kedua di kota Bogor. Peneliti mencari rumah mustahik penerima program karitatif (Paket Senyum) BAZNAS Kota Bogor yang tersebar di enam kecamatan di kota Bogor. Paket Senyum adalah bagian dari Program Bogor Peduli yang difokuskan pada pemberian bantuan rutin seperti sembako, biaya kontrakan rumah dan peralatan serta kebutuhan dasar rumah tangga. Dari enam kecamatan, sampel yang berhasil diwawancarai berlokasi di Kecamatan Bogor Barat, Tanah Sareal, dan Bogor Selatan.

Pertimbangan pemilihan lokasi untuk penelitian kedua adalah jarak tempuh, alamat yang jelas, dan kemudahan akses ke rumah mustahik. Kedua penelitian ini dilaksanakan pada bulan Mei hingga Juli 2013.

\subsection{Metode Pemilihan Sampel}

Pemilihan sampel dilakukan dengan menggunakan metode purposive sampling (sengaja), yaitu prosedur memilih sampel berdasarkan pertimbangan karakteristik yang cocok berkaitan dengan contoh yang diperlukan untuk menjawab tujuan penelitian (Juanda 2009). Pertimbangan dalam pengambilan sampel yaitu berdasarkan program pendayagunaan zakat yang aktif berjalan dan periode waktunya yang sudah cukup lama yang disesuaikan dengan tema penelitian. Sampel yang diambil dalam penelitian ini sebanyak 60 responden. Mereka terdiri dari 30 responden penerima program kesehatan yang telah terdaftar sebagai pasien lebih dari 6 bulan dan rutin datang berobat minimal 2 minggu sekali di Poliklinik Ibnu Sina Tirta Pakuan, dan 30 responden peserta program Paket Senyum yang rutin menerima bantuan setiap bulan selama lebih dari 6 bulan.

\subsection{Metode Analisis dan Pengolahan Data}

Metode analisis yang digunakan dalam penelitian ini terdiri atas :

1. Uji t-statistik untuk membuktikan perubahan pendapatan yang terjadi setelah adanya distribusi zakat.

2. Estimasi nilai IPM tingkat individu mustahik, untuk menganalisis peran zakat terhadap IPM.

3. Indikator-indikator kemiskinan, yaitu headcount ratio index $(\mathrm{H})$, poverty gap index $\left(\mathrm{P}_{1}\right)$, income gap indeks (I), dan Sen index of poverty (P2), yang digunakan untuk menganalisis peran zakat terhadap tingkat kemiskinan.

\subsubsection{Metode Analisis Perubahan Pendapatan Mustahik}

Untuk melihat apakah terjadi perubahan pendapatan mustahik karena adanya distribusi zakat, digunakan analisis uji t-statistik. Uji t-statistik merupakan salah satu metode pengujian hipotesis untuk data berpasangan atau data tidak bebas. Uji ini sering dilakukan untuk mengetahui apakah terdapat perbedaan nilai sebelum dan sesudah percobaan. Uji kali ini dilakukan untuk mengetahui apakah ada perbedaan sebelum dan sesudah distribusi zakat. Data yang digunakan adalah data pendapatan dengan dan tanpa zakat dengan ragam tidak diketahui.

Hipotesis uji $t$ :

$\mathrm{H}_{0}: \mu=0$

$\mathrm{H}_{1}: \mu>0$

Statistik uji : $\quad \mathrm{t}_{\text {hit }}=\frac{\bar{d}}{S d / \sqrt{n}}$ 


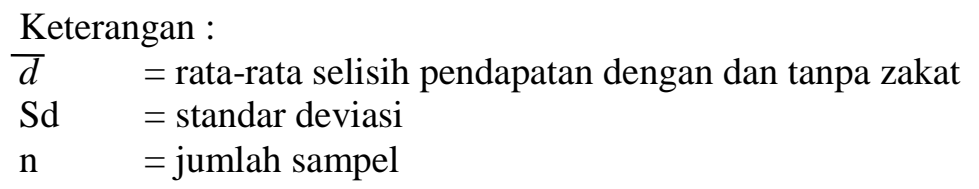

\subsubsection{Metode Analisis Peran Zakat terhadap IPM}

Nilai IPM diperoleh dengan menggabungkan tiga nilai indeks yang terdiri dari indeks angka harapan hidup, indeks pendidikan, dan indeks daya beli. Nilai indeks ini menggunakan standar internasional yang digabungkan dengan standar nasional. Formulanya sebagai berikut (Sen dan Anand 1994):

$$
\text { IPM = 1/3 (indeks angka harapan hidup) + 1/3 (indeks pendidikan) + 1/3 (indeks daya beli) }
$$

Metode yang digunakan pada penelitian ini sedikit berbeda dengan metode standar yang digunakan UNDP. metode yang digunakan UNDP adalah untuk perbandingan antar negara dan antar tingkat daerah lokal. Namun penelitian kali ini menggunakan pendekatan baru yang mengestimasi pada tingkat keluarga atau individu. Formulanya mengacu pada penelitian yang pernah dilakukan Nurzaman (2010). Estimasi secara rinci untuk masing-masing komponen IPM adalah sebagai berikut.

\section{Indeks Angka Harapan Hidup}

Indeks angka harapan hidup yang saat ini digunakan oleh UNDP dan beberapa negara dalam mengestimasi IPM ditingkat nasional adalah dengan menganggap kondisi ketika individu lahir. Demikian juga untuk tingkat provinsi dan kabupaten, telah sesuai dengan standar nilai IPM internasional. Namun dalam penelitian ini, untuk memperkirakan nilai indeks harapan hidup pada tingkat individu akan dilakukan penyesuaian metode dengan mempertimbangkan variasi sebaran dari populasi. Dengan kata lain, untuk mendapatkan angka harapan hidup seseorang pada usia tertentu, digunakan standar harapan hidup saat lahir yang sudah terdapat di BPS, dan apabila data tersebut belum ada maka digunakan data dari WHO (World Health Organization). Spesifikasi model sebagai berikut:

$$
\mathrm{IHi}=\frac{E x a, g,(i)-E x a, g,(\min )}{E x a, g,(\max )-E x a, g(\min )}
$$

Keterangan:

IHi $\quad=$ indeks harapan hidup individu (i)

Exa, $g,(i) \quad=$ harapan hidup seorang individu (i) yang disesuaikan dengan usia dan jenis kelamin

Exa, $g(\max )$ dan Exa, $g(\min )$ adalah data standar internasional untuk harapan hidup maksimum dan minimum yang diperoleh dari WHO dengan rentang nilai dari 0 tahun sampai 100 tahun.

\section{Indeks Pendidikan}

Indeks pendidikan menggunakan dua indikator yaitu rata-rata lama sekolah dan tingkat melek huruf. Rata-rata lama sekolah merupakan rata-rata jumlah tahun yang telah dihabiskan oleh penduduk usia 15 tahun ke atas diseluruh jenjang pendidikan formal yang dijalani. Dengan kata lain, indikator ini dihitung dengan menggunakan dua variabel secara simultan yaitu tingkat/kelas yang sedang/pernah dijalani dan jenjang pendidikan yang ditamatkan. Angka melek huruf juga diperlakukan untuk penduduk usia 15 tahun atau lebih dengan indikator yang diperoleh dari kemampuan membaca dan menulis. Perhitungan dalam penelitian ini menggunakan standar pemerintah Indonesia.

Untuk indikator melek huruf, dua batas yang digunakan untuk maksimum 100 dan minimum 0 , yang menggambarkan kondisi 100 adalah masyarakat yang mampu membaca dan menulis dan kondisi 0 untuk sebaliknya. 
Kemudian pola ini dihitung dengan indeks pendidikan :

Keterangan:

Indeks pendidikan $\left.=\left\{\frac{2}{3}\left[\frac{L i t-0}{100-0}\right]+\frac{1}{3[L S-0)} /(15-0)\right] x 100\right\}$

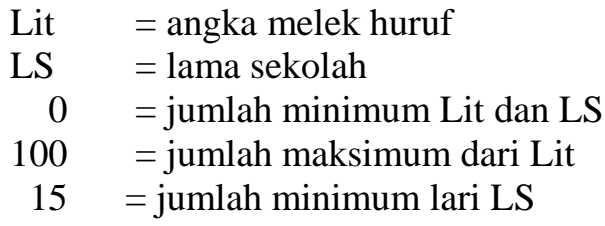

\section{Indeks Daya Beli}

Indeks pendapatan atau daya beli seseorang diukur dengan kualitas standar hidup yang layak. Pada penelitian ini, standar hidup yang layak seorang individu akan dihitung secara langsung dengan menyesuaiakan pengeluaran riil perkapita. Langkah pertama adalah dengan menghitung pengeluaran pendapatan bulanan keluarga masing-masing mustahik. Komponen pengeluaran mengikuti metode standar yang digunakan pemerintah yang didasarkan pada harga 27 komoditas. Namun, pada penelitian ini komoditas tersebut mengalami beberapa penyederhanaan yang diseseuaikan dengan kondisi mustahik dilapangan. sehingga menjadi lebih sederhana dan mudah dipahami.

Langkah berikutnya adalah menyesuaikan nilai paritas daya beli (PPP) dari pengeluaran ke dalam unit Dolar AS. Metode ini sering digunakan oleh banyak negara untuk menyesuaikan nilai pendapatan domestik bruto (PDB) perkapita agar dapat melakukan perbandingan standar dalam perhitungan IPM di tingkat internasional, formulanya adalah sebagai berikut:

\section{PPP yang disesuaikan $(\mathrm{Xij})=$ pengeluaran keluarga per tahun $\mathrm{x}(\mathrm{PDB}$ deflator Indonesia/PDB deflator AS)}

Selanjutnya, untuk mendapatkan indeks standar hidup yang layak adalah dengan memasukkan PPP yang telah disesuaikan ke dalam formula berikut,

$$
\text { Indeks daya beli }=\frac{\log x i j-\log x \min }{\log x \max -\log x \min }
$$

Keterangan:

$\mathrm{X} i j \quad=$ daya beli yang telah disesuaikan ke keluarga $(i)$

$x \min =$ daya beli minimum selama setahun di tingkat internasional yang telah ditetapkan UNDP yakni sebesar US\$100

$x \max =$ daya beli maksimum untuk setahun di tingkat internasional yang telah ditetapkan UNDP sebesar US\$ 40000.

\subsubsection{Metode Analisis Peran Zakat terhadap Tingkat Kemiskinan}

Untuk menganalisis peran zakat terhadap tingkat kemiskinan mustahik, digunakan beberapa indikator kemiskinan. Indikator kemiskinan yang digunakan pada penelitian ini terdiri atas headcount ratio index $(\mathrm{H})$, poverty gap index $\left(\mathrm{P}_{1}\right)$, income gap index (I), dan Sen index of poverty (P2). Berikut akan dijelaskan mengenai masing-masing indikator tersebut.

\section{Headcount Ratio Index (H)}

Headcount ratio index merupakan indikator kemiskinan yang mengukur jumlah orang miskin yang berada di bawah garis kemiskinan. Kategori miskin didasarkan pada standar garis kemiskinan yang dikeluarkan BPS. 
Adapaun rumus dari dari rasio ini adalah :

$$
\mathrm{H}=\frac{q}{n}
$$

Keterangan :

$\mathrm{H} \quad=$ headcount ratio index

$\mathrm{q} \quad=$ jumlah keluarga mustahik yang berada di bawah garis kemiskinan

$\mathrm{n} \quad=$ jumlah observasi

Garis kemiskinan keluarga diperoleh dari mengalikan garis kemiskinan per kapita per bulan dengan rata-rata besar ukuran keluarga. Garis kemiskinan kota Bogor tahun 2011 adalah Rp 305.870. Penggunaan headcount ratio index pada penelitian ini bertujuan untuk mengukur seberapa banyak mustahik yang berada dibawah garis kemiskinan dan menggambarkan berapa jumlah mustahik yang dapat dikurangi melalui pendayagunaan zakat. Apabila nilai dari indeks headcount ini berkurang, maka berarti pendayagunaan zakat memiliki dampak yang positif, karena mampu mengurangi jumlah mustahik yang hidup dengan pendapatan di bawah garis kemiskinan. Atau dengan kata lain, semakin kecil nilai headcount ratio index, maka jumlah penduduk miskin semakin sedikit.

\section{Poverty Gap Index $\left(\mathrm{P}_{1}\right)$ dan Income Gap Index (I)}

Untuk menganalisis tingkat kedalaman kemiskinan digunakan dua instrumen yaitu poverty gap index $\left(\mathrm{P}_{1}\right)$ untuk mengukur kesenjangan kemiskinan dan income gap index (I) untuk mengukur indeks kesenjangan pendapatan. Poverty gap index (P1) menunjukkan selisih antara pendapatan agregat komunitas masyarakat miskin dengan garis kemiskinan atau mengukur berapa jarak rata-rata pendapatan agregat kelompok miskin dengan garis kemiskinan. Indeks poverty gap diukur dengan satuan mata uang dengan formula sebagai berikut:

$$
\mathrm{P}_{1}=\left[\sum_{i=1}^{q}\left(Z-y_{i}\right)\right] / q
$$

Keterangan:

$\mathrm{P}_{1}=$ kesenjangan kemiskinan

$\mathrm{Z}=$ garis kemiskinan keluarga

$\mathrm{y}_{\mathrm{i}}=$ pendapatan keluarga mustahik ke-i

$\mathrm{q} \quad=$ jumlah keluarga mustahik yang berada di bawah garis kemiskinan

Jika setelah distribusi zakat, nilai indeks ini mengalami penurunan, berarti zakat memiliki pengaruh yang positif dalam pengurangan tingkat kesenjangan kemiskinan. Atau dengan kata lain, semakin kecil indeks ini, maka semakin sedikit selisih (gap) antara pendapatan agregat komunitas masyarakat miskin dengan garis kemiskinan sehingga kesejahteraan semakin baik.

Income Gap Index (I) mengukur Prosentase rata-rata kesenjangan pendapatan setiap orang miskin terhadap batas kemiskinan. Indeks ini dibuat oleh Amartya Sen untuk menormalisasikan kesenjangan kemiskinan keseluruhan populasi menjadi kesenjangan kemiskinan rata-rata individu (Beik 2010).

Formula untuk mengukur indeks kesenjangan pendapatan yaitu :

$$
\mathrm{I}=\sum_{i=\in S(z)} \frac{g i}{q z}
$$

Keterangan:

$\mathrm{I}=$ indeks kesenjangan kemiskinan pendapatan

$\mathrm{g}_{\mathrm{i}}=\mathrm{z}-\mathrm{y}_{\mathrm{i}}$, selisih pendapatan mustahik ke-i dengan garis kemiskinan

$\mathrm{q}=$ jumlah keluarga mustahik yang berada di bawah garis kemiskinan 
$\mathrm{z}=$ garis kemiskinan keluarga

$\mathrm{y}_{\mathrm{i}}=$ pendapatan keluarga mustahik ke-i

Semakin kecil nilai rasio ini, maka semakin sedikit orang miskin dalam komunitas tersebut. Apabila keberadaan program pendayagunaan zakat mampu menurunkan nilai indeks income gap ini, maka zakat memiliki dampak yang positif terhadap penurunan tingkat kedalaman kemiskinan.

\section{Sen Index of Poverty (P2)}

Sen index of poverty (P2) atau indeks keparahan kemiskinan menggambarkan ketimpangan pendapatan antar penduduk miskin. Formula untuk indeks Sen adalah :

$$
\mathrm{P}_{2}=\mathrm{H}\left[\mathrm{I}+(1-\mathrm{I}) \mathrm{G}_{\mathrm{p}}\right]
$$

Keterangan :

$\mathrm{P}_{2}=$ sen index of poverty

$\mathrm{H}=$ headcount ratio index

$\mathrm{I}=$ income gap index

$\mathrm{G}_{\mathrm{p}}=$ gini coefficient of the poor

Nilai indeks gini berkisar antara 0-1.

Untuk, Indeks gini $=0$ menandakan pemerataan pendapatan yang sempurna

$0<\mathrm{IG}<0.3 \quad$ menandakan kesenjangan pendapatan rendah

$0.3 \leq \mathrm{IG} \leq 0.5 \quad$ menandakan kesenjangan pendapatan sedang

$\mathrm{IG} \geq 0.5 \quad$ menandakan kesenjangan pendapatan tinggi

Formula untuk menghitung indeks gini adalah:

$\mathrm{IG}=1-\sum_{n=1}^{n} f p i\left(F c i+F c_{i-1}\right)$

Keterangan:

IG = indeks gini

Fpi $=$ frekuensi keluarga dalam kelas pendapatan ke-i

Fci $=$ frekuensi kumulatif dari total pendapatan dalam kelas pendapatan ke-i

$\mathrm{Fc}_{\mathrm{i}-1}=$ frekuensi kumulatif dari total pendapatan dalam kelas pendapatan ke (i-1)

Semakin kecil indeks ini, maka sedikit Prosentase orang miskin, selisih (gap) antara pendapatan agregat masyarakat miskin dengan garis kemiskinan juga semakin sedikit, dan kesenjangan pendapatan semakin kecil. Apabila setelah pendayagunaan zakat, nilai indeks ini mengalami penurunan, maka artinya zakat memiliki dampak positif dalam mengurangi tingkat keparahan kemiskinan.

\section{Hasil dan Pembahasan}

\subsection{Analisis Demografi Responden dan Perubahan Pendapatan}

Responden yang digunakan dalam penelitian ini merupakan mustahik dari program kesehatan sub program aktivitas klinik dan program kemanusiaan sub program Paket Senyum. Total responden adalah sebanyak 60 orang. Karakteristik demografi responden akan dijelaskan pada Tabel 1.

\section{Tabel 1 Karakteristik Demografi Responden}




\begin{tabular}{|c|c|c|}
\hline Karakteristik demografi & Jumlah & Presentase \\
\hline $\begin{array}{l}\text { Jenis kelamin KK } \\
\text { laki-laki } \\
\text { perempuan }\end{array}$ & $\begin{array}{l}19 \\
41\end{array}$ & $\begin{array}{l}31.7 \\
68.3\end{array}$ \\
\hline $\begin{array}{l}\text { Usia } \\
21-35 \text { tahun } \\
36-50 \text { tahun } \\
51-65 \text { tahun } \\
66-80 \text { tahun } \\
>81 \text { tahun }\end{array}$ & $\begin{array}{c}2 \\
8 \\
27 \\
21 \\
2\end{array}$ & $\begin{array}{c}3.3 \\
13.3 \\
45 \\
35 \\
3.3 \\
\end{array}$ \\
\hline $\begin{array}{l}\text { Pendidikan } \\
\text { Tidak sekolah } \\
\text { Tidak tamat SD } \\
\text { SD } \\
\text { SMP } \\
\text { SMA } \\
\text { Diploma/Sarjana } \\
\end{array}$ & $\begin{array}{c}21 \\
13 \\
15 \\
6 \\
5 \\
-\end{array}$ & $\begin{array}{c}35 \\
21.7 \\
25 \\
10 \\
8.3 \\
-\end{array}$ \\
\hline $\begin{array}{l}\text { Besar ukuran keluarga } \\
1-3 \text { orang } \\
4-6 \text { orang } \\
>7 \text { orang }\end{array}$ & $\begin{array}{c}35 \\
19 \\
6\end{array}$ & $\begin{array}{c}58.3 \\
31.7 \\
10\end{array}$ \\
\hline $\begin{array}{l}\text { Pendapatan sebelum zakat (rupiah } \\
\text { per bulan) } \\
600.000 \\
600.000-1.200 .000 \\
>1200.000\end{array}$ & $\begin{array}{l}26 \\
24 \\
10\end{array}$ & $\begin{array}{c}43.3 \\
40 \\
16.7\end{array}$ \\
\hline
\end{tabular}

Berdasarkan Tabel 1, mayoritas keluarga adalah berjenis kelamin perempuan (68.3 persen). Hal ini menunjukkan bahwa sebagian besar tanggung jawab kepala keluarga dipegang oleh perempuan dan merupakan sesuatu yang tidak wajar. Dari segi usia, mayoritas responden berada pada usia yang tidak produktikf yaitu 51-65 tahun (45 persen), kemudian diikuti kelompok usia 66-80 tahun (21 persen). Hal ini mengindikasikan mayoritas responden merupakan kelompok usia tua yang memiliki peluang sangat kecil untuk meningkatkan kualitas taraf hidupnya.

Dari aspek pendidikan, mayoritas responden tidak pernah bersekolah (35 persen) dan sebagian besar tidak tamat SD (13 persen) dan tamat SD (15 persen). Hal ini mengindikasikan bahwa tingkat pendidikan responden masih rendah. Dari segi besar ukuran keluarga, mayoritas responden memiliki tanggungan keluarga 1-3 orang (35 persen). Kemudian diikuti dengan keluarga dengan tanggungan 46 orang (19 persen). Hal ini bisa diindikasikan responden memiliki tanggungan yang cukup besar. Dari segi pendapatan, mayoritas responden berada pada pendapatan dibawah Rp 600 ribu per bulan (43.4 persen).

Secara umum dapat disimpulkan bahwa karakteristik responden penelitian ini adalah kepala keluarga didominasi perempuan dengan usia yang tidak produktif lagi, sudah menikah dan memiliki tanggungan berkisar 1-3 orang, tidak pernah sekolah, dan berpenghasilah dibawah Rp 600000 per bulan.

Berdasarkan hasil perhitungan uji t-statistik diperoleh nilai $t_{\text {hit }}$ (18.76) lebih besar dari $t_{\text {tabel }}(1.96)$ sehingga tolak $\mathrm{H}_{0}$. Artinya, pendapatan setelah zakat berbeda nyata pada taraf $\alpha=5$ persen terhadap pendapatan sebelum distribusi zakat. Sehingga dapat disimpulkan bahwa pemberian zakat kepada mustahik memberikan pengaruh nyata pada tingkat pendapatannya.

\subsection{Pengaruh Zakat terhadap IPM Mustahik}

Berdasarkan hasil estimasi perhitungan IPM tingkat individu pada mustahik program pendayagunaan zakat oleh BAZNAS Kota Bogor, dari 60 responden diperoleh rata-rata nilai komponen IPM sebagai berikut:

\section{Tabel 2 Nilai Komponen IPM}




\begin{tabular}{|l|c|c|}
\hline \multicolumn{1}{|c|}{ Komponen IPM } & Nilai & Indeks (\%) \\
\hline Indeks angka harapan hidup & 0.34 & 34 \\
\hline Indeks Pendidikan & 0.55 & 55 \\
\hline Indeks paritas daya beli (PPP) tanpa zakat & 0.53 & 53 \\
\hline Indeks paritas daya beli (PPP) dengan zakat & 0.59 & 59 \\
\hline IPM sebelum distribusi zakat & 0.47 & 47 \\
\hline IPM setelah distribusi zakat & 0.49 & 49 \\
\hline Perubahan IPM (\%) & 4.1 & \\
\hline
\end{tabular}

Menurut BPS Kota Bogor (2012), jika nilai IPM lebih kecil dari 50, maka statusnya adalah rendah. Jika $50 \leq$ IPM $<66$ maka nilainya menengah bawah. Jika $66 \leq$ IPM $<80$ maka nilai IPM-nya adalah menengah atas, dan jika IPM $\geq 80$ maka nilainya adalah tinggi. Berdasarkan data pada Tabel 2, nilai IPM mustahik sebelum dan setelah distribusi zakat berada pada tingkatan rendah. Sebelum distribusi zakat IPM mustahik sebesar 47 dan setelah distribusi zakat naik menjadi 49. Artinya, meski terjadi kenaikan nilai IPM mustahik sebesar 4.1 persen, namun kualitas SDM mustahik masih berada pada kategori rendah.

Hasil analisis tiap komponen IPM menunjukkan perubahan yang tidak terlalu signifikan. Nilai Indeks angka harapan hidup mustahik adalah 0.34. Artinya, rata-rata kemungkinan hidup bayi-bayi yang lahir pada tahun tersebut sekitar 34 persen dan dapat bertahan hidup hingga umur 34 tahun. Namun, melihat fakta yang terjadi sekarang, banyak tahun yang dapat ditempuh oleh mustahik berkisar 60 tahun ke atas. Hasil ini berdasarkan survei langsung ke para mustahik yang menjadi sampel penelitian ini. Dari 60 mustahik yang diwawancarai, semuanya berusia di atas 34 tahun. Ini membuktikan bahwa estimasi perhitungan indeks angka harapan hidup belum bisa dijadikan fokus untuk mengukur kesejahteraan penduduk di bidang kesehatan.

Tabel 3 Rata-rata Usia Mustahik

\begin{tabular}{|c|c|}
\hline Jarak usia (tahun) & Jumlah mustahik (orang) \\
\hline$\leq 50$ & 10 \\
\hline $51-65$ & 27 \\
\hline $66-80$ & 21 \\
\hline$>80$ & 2 \\
\hline
\end{tabular}

Komponen IPM berikutnya adalah indeks pendidikan. Berdasarkan data-data yang diperoleh dari penelitian, angka melek huruf mustahik sebesar 73 persen. Hal ini berarti sebesar 27 persen mustahik yang berumur di atas 15 tahun tidak bisa baca tulis. Sedangkan, rata-rata lama sekolah mustahik berkisar 4.2 tahun. Artinya rata-rata jumlah tahun yang dijalani oleh mustahik usia 15 tahun ke atas dalam menempuh semua jenis pendidikan formal adalah sebesar 4.2 tahun. Berdasarkan dua indikator tersebut, maka diperoleh nilai indeks pendidikan sebesar 0.55 .

Komponen IPM yang digunakan dalam mengukur standar hidup masyarakat adalah dengan indeks daya beli. Pada penelitian ini, untuk melihat adanya pengaruh dari distribusi zakat, maka paritas daya beli mustahik dihitung sebelum dan setelah distribusi zakat. Indeks paritas daya beli mustahik sebelum distribusi zakat adalah sebesar 0.53. Sedangkan setelah distribusi zakat indeks paritas daya beli mustahik naik menjadi 0.59. Prosentase perubahannya mencapai angka 10.2 persen. Ini mengindikasikan bahwa paritas daya beli mustahik mengalami peningkatan sebesar 10.2 persen dan berimplikasi positif terhadap standar hidup kelompok mustahik.

Hasil analisis dari ketiga komponen IPM di atas menunjukkan bahwa komponen indeks angka harapan hidup yang paling mempengaruhi rendahnya nilai IPM mustahik. Ini karena indeks angka harapan hidup bukan komponen yang memiliki hubungan langsung dengan distribusi zakat. Dana zakat yang disalurkan pada program ini lebih kepada bantuan uang dan sembako yang berpengaruh secara langsung pada indeks paritas daya beli. 


\subsection{Pengaruh Zakat terhadap Tingkat Kemiskinan Mustahik}

Setelah memperoleh nilai IPM dari mustahik, selanjutnya dilakukan analisis dengan menggunakan indikator kemiskinan. Hal ini untuk melihat lebih jelas bagaimana peran zakat dalam pembangunan manusia. Tabel 4 memberikan hasil penelitian terkait indikator kemiskinan yang ada.

\section{Tabel 4 Indikator Kemiskinan}

\begin{tabular}{|c|c|c|c|}
\hline Indeks Kemiskinan & $\begin{array}{c}\text { Sebelum distribusi } \\
\text { zakat }\end{array}$ & $\begin{array}{c}\text { Setelah distribusi } \\
\text { zakat }\end{array}$ & $\begin{array}{c}\text { Prosentase Perubahan } \\
(\%)\end{array}$ \\
\hline $\mathrm{H}$ & 0.85 & 0.77 & 9.8 \\
\hline $\mathrm{P}_{1}$ (rupiah) & 536265.89 & 301755.66 & 43.73 \\
\hline $\mathrm{I}$ & 0.43 & 0.24 & 43.73 \\
\hline $\mathrm{P}_{2}$ & 0.84 & 0.75 & 10.8 \\
\hline $\mathrm{G}_{\mathrm{p}}$ & 0.98 & 0.97 & 1 \\
\hline
\end{tabular}

Berdasarkan Tabel 4, nilai indeks headcount ratio sebelum distribusi zakat adalah sebesar 0.85 yang artinya dari seluruh rumah tangga terdapat 85 persen keluarga yang dikategorikan miskin berdasarkan garis kemiskinan keluarga. Kehadiran program pendayagunaan zakat menyebabkan nilai headcount ratio mengalami penurunan dari 0.85 menjadi 0.77. Ini menunjukkan bahwa pendayagunaan zakat memiliki dampak yang positif, karena mampu mengurangi jumlah mustahik yang hidup dengan pendapatan di bawah garis kemiskinan sebesar 9.8 persen.

Nilai indeks poverty gap atau kesenjangan kemiskinan mengalami penurunan dari Rp 536265.891 menjadi Rp 301 755.662. Artinya, sebelum terjadinya pendistribusian zakat, jarak antara rata-rata pendapatan rumah tangga miskin mustahik dengan garis kemiskinan adalah Rp 536 265.891. Dengan adanya program pendayagunaan zakat dari BAZNAS Kota Bogor, jarak ini dapat diperkecil menjadi Rp 301 755.662. Penurunan angka sebesar 43.73 persen mengindikasikan bahwa pendistribusian zakat yang dilakukan oleh BAZNAS Kota Bogor secara empirik mampu menurunkan tingkat kesenjangan kemiskinan keluarga mustahik.

Hal yang sama juga terjadi pada indeks kesenjangan pendapatan dimana indeks kesenjangan pendapatan turun dari sebelum distribusi zakat sebesar 0.43 menjadi 0.24 setelah distribusi zakat. Hal ini menujukkan keberadaan zakat mampu menurunkan nilai rasio kesenjangan pendapatan sebesar 43.73 persen. Dengan demikian, dapat disimpulkan bahwa tingkat kedalaman kemiskinan dapat direduksi oleh program pendistribusian zakat BAZNAS Kota Bogor.

Nilai indeks Sen atau tingkat keparahan kemiskinan sebelum adanya distribusi zakat sebesar 0.84 menunjukkan bahwa kelompok mustahik berada pada tingkat keparahan kemiskinan yang tinggi. Kehadiran program pendayagunaan zakat oleh BAZNAS Kota Bogor mampu mereduksi tingkat keparahan kemiskinan menjadi 0.75. Penurunan indeks Sen sebesar 10.8 persen ini mengindikasikan bahwa program zakat berdampak positif terhadap pengentasan kemiskinan.

Untuk melihat apakah terjadi kesenjangan dalam pemberian zakat kepada mustahik, digunakan analisis gini coefficient of the poor $\left(\mathrm{G}_{\mathrm{p}}\right)$. Nilai $\mathrm{G}_{\mathrm{p}}$ mustahik sebelum pemberian dana zakat adalah sebesar 0.98. Artinya, kesenjangan pendapatan mustahik sebelum distribusi zakat sangat tinggi. Setelah distribusi zakat $\mathrm{G}_{\mathrm{p}}$ mustahik mengalami penurunan manjadi 0.97. Perubahan $\mathrm{G}_{\mathrm{p}}$ mustahik hanya sebesar 1 persen. Hal ini mengindikasikan bahwa setelah pemberian zakat, kesenjangan pendapatan mustahik masih sangat tinggi. Ini bisa dikarenakan dalam distribusi zakat, BAZNAS Kota Bogor belum memperhatikan dari sisi pembobotan dana zakat yang diberikan kepada masing-masing mustahik. 


\section{Simpulan dan Saran}

\subsection{Simpulan}

Pendayagunaan zakat oleh BAZ Kota Bogor selama tahun 2009 sampai dengan tahun 2011 menunjukkan perkembangan yang fluktuatif. Total penerimaan zakat sempat mengalami penurunan yang cukup besar di tahun 2011. Sementara total penerimaan dari ZIS BAZ dan mitra BAZ menunjukkan peningkatan dari tahun ke tahun. Untuk penyaluran dana zakat berdasarkan asnaf, program yang menerima dana paling besar adalah program kemanusiaan, kemudian program kesehatan.

Distribusi zakat kepada mustahik menunjukkan terjadinya perubahan pada tingkat pendapatan mustahik. Dengan menggunakan Uji t-Statistik, ditemukan bahwa pendapatan mustahik sebelum dan setelah distribusi zakat berbeda pada taraf nyata 5 persen. Dengan kata lain, distribusi zakat dapat meningkatkan tingkat pendapatan mustahik.

IPM mustahik sebelum dan setelah distribusi zakat berada pada status rendah. Nilai IPM sebelum distribusi zakat sebesar 47 dan setelah distribusi zakat menjadi 49. Meski terjadi perubahan nilai IPM sebesar 4.1 persen dengan adanya program pendayagunaan zakat oleh BAZNAS Kota Bogor, nilai IPM mustahik tidak mengalami perubahan status.

Adapun pengaruh zakat terhadap kemiskinan sangat baik. Hasil analisis dari 60 mustahik menunjukkan bahwa nilai headcount index mustahik turun dari 0.85 menjadi 0.77 . Nilai poverty gap index mustahik mengalami penurunan dari sebelum distribusi zakat sebesar Rp 536265.89 menjadi Rp 301755.66 pasca zakat. Hal yang sama juga terjadi pada indeks kesenjangan pendapatan dimana indeks kesenjangan pendapatan turun dari sebelum distribusi zakat sebesar 0.43 menjadi 0.24 setelah distribusi zakat.

Nilai indeks Sen juga mengalami penurunan dari 0.84 menjadi 0.76 . Penurunan pada semua nilai indikator kemiskinan tersebut mengindikasikan bahwa program pendayagunaan zakat oleh BAZNAS Kota Bogor terbukti memiliki implikasi yang positif terhadap pengentasan kemiskinan dan berperan baik dalam meningkatkan pembangunan manusia.

Hasil analisis $G_{p}$ sebelum distribusi zakat merepresentasikan kesejangan pendapatan yang sangat tinggi diantara mustahik. Nilai $\mathrm{G}_{\mathrm{p}}$ mustahik sebelum menerima dana zakat adalah sebesar 0.98 . Mengalami penuruan menjadi 0.97 setelah mustahik menerima bantuan zakat. Perubahan $\mathrm{G}_{\mathrm{p}}$ mustahik hanya sebesar 1 persen. Hal ini mengindikasikan bahwa setelah pemberian zakat, kesenjangan pendapatan mustahik masih sangat tinggi. Ini bisa dikarenakan dalam distribusi zakat, BAZ Kota Bogor belum memperhatikan dari sisi pembobotan dana zakat yang diberikan kepada masing-masing mustahik.

\subsection{Saran}

Dari hasil penelitian di atas, maka ada beberapa saran yang dapat diberikan, yaitu :

1. BAZNAS Kota Bogor hendaknya memperhatikan kondisi pengembangan SDM mustahik, agar nilai IPM-nya dapat dinaikkan dari status rendah menjadi status yang lebih tinggi seperti menengah bawah. Dibutuhkan adanya pola edukasi yang tepat agar kualitas SDM mustahik ini dapat meningkat.

2. Masih tingginya kesenjangan pendapatan antar mustahik menunjukkan bahwa BAZNAS Kota Bogor memberikan besaran dana zakat yang sama untuk para mustahik. Seharusnya perlu diberikan pembobotan dan pembedaan antar mustahik dengan memperhatikan tingkat kebutuhan antar mustahik yang ada. Karena itu, analisis lebih dalam mengenai aspek kebutuhan hidup antar mustahik perlu dilakukan. 
3. Pemerintah Kota Bogor diharapkan dapat mendorong upaya penghimpunan ZIS di kota Bogor secara lebih optimal. Perlu dilakukan edukasi dan sosialisasi yang efektif agar masyarakat mau menyalurkan zakatnya melalui BAZNAS Kota Bogor.

\section{Daftar Pustaka}

Anriani. 2010. Analisis Dampak Zakat terhadap Tingkat Kemiskinan Mustahik : Studi Kasus Pendayagunaan zakat oleh BAZ Kota Bogor di Tiga Kecamatan Kota Bogor [Skripsi]. Bogor (ID): Institut Pertanian Bogor.

Beik IS. 2009. Analisis Peran Zakat dalam Mengurangi Kemiskinan: Studi Kasus Dompet Dhuafa Republika. Jurnal Zakat \& Empowering: 2:47-55.

Beik IS. 2010. Tiga Dimensi Zakat. Jakarta: Harian Republika.

[BAZ] Badan Amil Zakat Kota Bogor. 2013. Laporan Tiga Tahunan 2009-2011. Bogor (ID): BAZ Kota Bogor.

[BAZNAS] Badan Amil Zakat Nasional. 2013. [Internet diunduh 2013 Mei 01]. Tersedia pada : http://www.pusat.baznas.go.id. Jakarta (ID): BAZNAS

[BPS] Badan Pusat Statistik Kota Bogor. 2011. Bogor dalam Angka 2012. Bogor (ID): BPS Kota Bogor.

[BPS] Badan Pusat Statistik Kota Bogor. 2012. Hasil Proyeksi dan Sensus Penduduk 2010. Bogor (ID): BPS Kota Bogor.

Chapra MU. 2000. Sistem Moneter Islam. Basri IA, penerjemah. Jakarta (ID): Gema Insani Press.

[Depag] Departemen Agama Republik Indonesia. 1999. [Internet diunduh 2013 September 12]. Tersedia pada : http://www.kemenag.go.id. Jakarta (ID): Depag.

Hafidhuddin D. 2002. Zakat dalam Perekonomian Modern. Jakarta (ID): Gema Insani Press.

Juanda B. 2009. Metodologi Penelitian Ekonomi dan Bisnis. Bogor (ID): IPB Press.

Kuncoro M. 2010. Ekonomika Pembangunan. Jakarta (ID): Erlangga.

Marzali A. 2007. Antropologi dan Pembangunan Indonesia. Jakarta (ID): Kencana.

Meier GM. 1998. Leading Issues in Economic Development. Oxford University Press.

Nurzaman MS. 2010. Zakat and human development: an empirical analysis on poverty alleviation in Jakarta, indonesia. Center for Islamic economics and finance, Qatar faculty of Islamic studies, Qatar foundation. p 1-26.

Pramanik AH. 1993. Development and Distribution in Islam. Petaling Jaya: Pelanduk Publications.

Sen A dan Anand S. 1994. Human Development index : Methodology and Measurement. Human Development Report Office Occasional Papers.

Soedjatmoko.1995. Dimensi Manusia dalam Pembangunan-Pilihan Karangan Soedjatmoko. Jakarta (ID): Pustaka LP3ES Indonesia.

Suprayitno E. 2005. Ekonomi Islam. Yogyakarta (ID): Graha Ilmu.

[SUSENAS] Survei Sensus Nasional Kota Bogor. 2013. Laporan Sensus Kota Bogor. Bogor (ID): Susenas.

Torre R dan Moreno H. 2010. Advances in sub national measurement of the Human Development Index: The case of Mexico. Human Development Research Paper No.23.

Tsani T. 2010. Analisis Dampak Distribusi Zakat terhadap Tingkat Kemiskinan dan Kesenjangan Pendapatan : Studi Kasus Pendayagunaan Zakat oleh BAZDA Lampung Selatan [Skripsi]. Bogor (ID) : Institut Pertanian Bogor.

Qardhawi Y. 2001. Hukum-Hukum Zakat. Jakarta (ID): Lintera Antar Nusa. 